\title{
A Survey of Teachers' and Students' Perception of Sexual Harassment in Tertiary Institutions of Edo State, Nigeria
}

\author{
Justina Imonikhe, Ph. D \\ School of General Studies, Auchi Polytechnic, Auchi, Edo State, Nigeria \\ Oyaziwo Aluede, Ph. D. \\ Faculty of Education, Ambrose Alli University, Ekpoma, Edo State, Nigeria \\ E-mail: oyaziwoaluede@yahoo.com
}

Philipa Idogho, Ph. D

Rector, Auchi Polytechnic, Auchi, Edo State, Nigeria

$\begin{array}{lcc}\text { Received: June 3, } 2011 & \text { Accepted: July 28, 2011 } & \text { Published: January 1, } 2012 \\ \text { doi:10.5539/ass.v8n1p268 } & \text { URL: http://dx.doi.org/10.5539/ass.v8n1p268 }\end{array}$

\begin{abstract}
The study examined how teachers and students of tertiary institutions in Edo State of Nigeria perceived sexual harassment. The design of the study was descriptive (survey) research. The sample of the study consisted of two hundred lecturers and two hundred students of tertiary institutions in Edo state. A questionnaire, entitled "Lecturers' and Students' Perceptions of Sexual Harassment Scale" was used to gather data for the study. The results indicated that majority of the respondents agreed that sexual harassment is prevalent in schools and that sexual harassment impacts negatively on the academic performance of victims. Based on the findings, it was recommended among others that tertiary institutions should provide the framework where teachers and students can dialogue on issues bothering on students' and lecturers' relationships
\end{abstract}

Keywords: Sexual abuse, Gender violence, School violence, School failure, Academic stressor, Sexual assault, Academic fraud, College students

\section{Introduction}

Sexual harassment in Nigeria's universities appears to be under-researched and even less reported (Adamolekun, 1989). However, the Commission on the Review of Higher Education in Nigeria (CRHEN) (1991, as cited in Ladebo, 2001) suggests that the phenomenon is gradually assuming critical dimension in Nigeria's higher institutions of learning.

Sexual harassment is defined as unwelcome sexual advances, requests for sexual favours and other verbal or physical conduct of sexual nature (Aluede, 2000; Cohen, n.d). It is a silent disease that is seriously eroding academic excellence in tertiary institutions in Nigeria. It is often seen as a behaviour that is unwelcome (the recipient does not want it), unsolicited (the recipient did not ask for it), and repeated (the behaviour is not one isolated incident). A behaviour can be considered sexual harassment when: (a) submission to such conduct is explicitly or implicitly a term or condition for an individual's employment or participating in educational programmes; or (b) submission to, or rejection of such conduct by an individual is used as a basis for employment or academic decisions affecting the individual; or (c) when such conduct has the purpose or effect of unreasonably interfering with an employee's work performance or student's academic performance, creating an intimidating, hostile, or offensive working or learning environment(Anonymous, nd).

The definition of sexual harassment identifies the various behaviours that may constitute sexual harassment in a work environment. The first two provisions deal with unequal power relations between the employer/supervisor and employee/subordinate. An employer or a supervisor demands sexual gratification from the employee or subordinate in return for job benefits. In the academic environment, a parallel situation could be argued to arise when faculty propose to female students for sexual favours, in return for favourable examination results. The 
third provision refers to the existence of a hostile work environment, where the offending behaviour interferes with the satisfactory work performance of an employee. Fitzgerald, Gelfand and Drasgow (1995) further extended this definition by adding three empirically derived situations: unwanted sexual attention such as touching, hugging, stroking and demanding a date; sexual coercion, which relates to sexual advances with the promise of job-related benefits; and gender harassment, which refers to those verbal and non-verbal behaviours (such as jokes, taunts, gestures, and exhibition of pornographic materials)

Tertiary institutions in Nigeria have been bedevilled with obscene dressing by students, especially the female students, secret cult activities and drug abuse, to mention a few. Most of the female students almost go naked, display their navels and boobs and wearing what are just ample cleavages on display depicting size and shape of the private parts with minis that barely cover their buttocks. These are weapons of mass distraction and sexual harassment. Some of the students are so morally bankrupt that they rely absolutely on their womanhood to 'pass' their examinations. They seduce fellow male students or examiners to assist them write their examinations or award them pass marks as the case may be.

The general increase in the social vices in Nigerian tertiary institutions might be responsible for the general decline in the quality of graduates being turned out by Nigeria's tertiary institutions. An evaluation of the quality of graduates from Nigerian tertiary institutions based mainly on a series of questions put to major employers of Nigerian graduates as a way of assessing graduates' level of preparation and performance on the job; the result showed that the quality of the graduates is deteriorating (The Scholar, 2001). There is also a general perception that sexual harassment is prevalent in most or all university campuses in Nigeria and that the phenomenon had been on the increase in the last 10 years (Ladebo, 2001).

Sexual harassment is an all too familiar part of the everyday experience in tertiary institutions and it is characterized as one of the most omnipresent and rampant form of gender-based violence which many ladies face daily (American Association of University Women, 2006). Sexual harassment is complex, not always unidirectional, played down by all concerned, unreported and considered a serious moral and social problem in tertiary institutions. It may take several forms: male lecturers to female students, male students to female students, male lecturers to female lecturers and non-academic staff and so on. Female students are in most cases at great risk, while the male academic staff are likely to be the perpetuators of sexual harassment in tertiary institutions. This trend is amazing and disturbing in an environment that is often believed to be a centre of excellence, be a moulding and filtering ground for building virile leaders and intellectuals that will mount the stage of leadership of the country tomorrow.

\subsection{Prevalence and Impact of Sexual Harassment}

In the school system, there are implicit and explicit coercive sexual behaviour that are used to control, influence or affect the educational opportunities, grades, and / or learning environment of a student. These include withholding or threatening to withhold grades earned or deserved, submitting or threatening to submit an underserved performance evaluation, denying or threatening to deny a scholarship recommendation or college application. Thus, experiencing sexual harassment can have negative effects on a victim's psychological and physical health (Gutek \& Koss, 1993; Gutek, 1993; Schineider, Swan \& Fitzgerald, 1997). Problematic reactions include anger, reduced self-esteem, loss of confidence, depression, anxiety, psychological trauma and powerlessness on the part of the victims. Victims may also have difficulty in their personal relationships and in sexual adjustment (loss of desire, for example). Sexual harassment can also lead to any of the following: contracting sexually transmitted infections and unwanted pregnancies; lack of concentration in studies, thereby leading to poor academic performance; poor image; failure to achieve the institutions' objectives of producing wholesome graduates for the Nigerian society; increased alcohol consumption; smoking; and dependence on drugs (Davidson \& Fielden, 1999). Sexual harassment can also produce fallout on the jobs. For females who are harassed, it may lead them to become less productive, less satisfied with their jobs and less committed to their work compared to those who do not experience sexual harassment.

Studies on sexual harassment of students have established that sexual harassment is a pervasive and persistent form of violence experienced often on a daily basis by the majority of females. For example, the 1994 study by the Ontario Secondary school Teachers' Federation (OSSTF) (1994) found that over $80 \%$ of the female students surveyed had been sexually harassed by another student and $20 \%$ of them by school staff. The study also revealed that about $1 \%$ of boys had also been sexually harassed. The range of sexual harassment reported within school setting was extensive. The ranges included sexual comments, jokes, gestures, touch and pinched in sexual way. In all the cases, girls reported more serious and negative impacts on their school performance than the boys. These impacts included difficulty in concentration, fear, ill at ease, lowered self-esteem and lower grades. A 
similar study of four Nigerian universities revealed that students identified sexual harassment as being among the stressors hindering academic work (Ladebo, 2001).

Too often, sexual harassment is viewed by students, lecturers, staff and parents as just part of life. Denial, dismissal and minimization have all been used by the public to mask the reality (Fadipe \& Oluchukwu, 1999; Kopels \& Dupper, 1999). Cases of sexual harassment are not often reported for fear of victimization and stigmatisation.

\subsection{Rationale for the Study}

Sexual harassment of female students in Nigerian tertiary institutions is widely acknowledged; yet teachers' and students' perception of school sexual harassment and its impact on the mental and academic well being of the victims is not only neglected, but also virtually ignored. Though, few studies have reported incidents of sexual harassment in Nigeria, and that most teachers and students perceive sexual harassment as part of life; other studies indicated that the perception of sexual harassment was largely that female dressing and attitudes increase their vulnerability to sexual harassment (Opong, 1995; Irtwange, 2004). In all these studies about sexual harassment in Nigeria, the consequences of sexual harassment on the victims are either grossly unreported or nothing of that nature was ever surveyed. Therefore, it became very imperative for this endeavour to among other survey teachers' (who are the perpetuators) and students' (who are victims) perception of sexual harassment, especially with regards to its impact on victims' academic performance.

As it is common knowledge in our tertiary institutions of learning, moral excellence is no longer encouraging especially with regards to campus prostitution, sexual harassment and gratification, as well as cultism and bribery from the supposed mentors and tutors. One imagines a situation where these lecturers have turned the educational system to a goldmine, demanding sexual gratification before they award pass marks to graduate their victims who are mostly females. Thus, it seems appropriate therefore to assess the perception of teachers and students regarding sexual harassment. To achieve this, the study addressed the following questions: How do students and lecturers perceive the prevalence of incidents of sexual harassment? And what impact does sexual harassment hold for school performance?

\section{Method of Study}

\subsection{Participants}

This study adopted the descriptive (survey) study. Data for this study were obtained quantitatively and qualitatively from a simple randomly selected sample of 200 lecturers and 200 students from government owned tertiary institutions in Edo state of Nigeria during the 2009/ 2010 academic session. Specifically, of the 400 respondents who participants in this study, 200 of them were from the university and the remaining 200 were from the polytechnic. The demographic characteristics of these participants included 100 male students and 100 female students, 120 male lecturers and 80 female lecturers.

\subsection{Measures}

The Lecturers' and Students' Perception of Sexual Harassment Scale used to obtain data for this study had two sections. Section A is an adaptation of Stein, Marshall and Tropp's (1993) scale on types of sexual harassment in schools. The modification of the scale became necessary to address the inherent peculiarities in the Nigerian society. This section was made up of 12 items raised on a four- point scale with response ranging from strongly agree to strongly disagree. Section B of the instrument was constructed by the researchers and designed to obtain information from lecturers and students on the impact of sexual harassment on students' academic performance. This section was made of eight items raised on a four- point scale with responses ranging from strongly agree to strongly disagree.

The instrument was content validated by eight persons, four academic staff and four students of the Ambrose Alli University, Ekpoma, Nigeria and Auchi Polytechnic, Auchi, Nigeria. Based on their corrections/modifications on the instrument, the final version of the instrument was drawn up. The reliability of the instrument was determined through the test- retest method on a sample of 20 students of University of Benin, Benin city, Nigeria. The scale yielded a reliability co-efficient of 0.85 .

\subsection{Procedures}

Copies of the questionnaire were personally administered to the participants in their schools by current researchers with the assistance of research assistants. Current researchers trained the research assistants on the contents and mode of administration of the questionnaire. Copies of the questionnaire were retrieved from the 
respondents the same day. The researchers waited for collection in order to avoid any complaint of misplacement. The analysis of data was carried out using frequency counts and simple percentages

\section{Results}

The data collected were analyzed and categorized under the following:

\subsection{Perception of Teachers and Students of the Prevalence of Forms of Sexual Harassment}

Frequencies and percentages were calculated to determine teachers' and students' perception of the prevalence of sexual harassment in schools. Results are presented in Table 1.

From Table 1 above, it could be inferred that majority of the teachers and students agreed on the prevalence of sexual harassment in their schools. The range of sexual harassment reported by teachers and students in tertiary institutions was extensive. Specifically, majority of the teachers(with the percentage scores of the respondents in parenthesis) reported the following forms of sexual harassment: sexual comments, jokes, gesture(94.5\%); touched, grabbed or punched in a sexual way $(95 \%)$; leaned over or cornered $(82 \%)$; receiving sexual notes or pictures $(89 \%)$; pressured to do something sexual other than kissing $(95.5 \%)$; intentionally brushed up against in a sexual way $(97 \%)$; had your way blocked in a sexual way $(80 \%)$ : had clothing pulled in a sexual way $(92 \%)$; had clothing pulled off or down (75\%); forced to kiss someone (76\%); and had sexual messages written about you on public walls $(80 \%)$. Also majority of the students (with the percentage scores of the respondents in parenthesis) surveyed reported the following forms of sexual harassment: sexual comments, jokes, gesture (99\%); touched, grabbed or punched in a sexual way $(97 \%)$ ); leaned over or cornered $(92 \%)$; receiving sexual notes or pictures (97\%); pressured to do something sexual other than kissing (93.5\%); intentionally brushed up against in a sexual way(92.5\%); had your way blocked in a sexual way(88.5\%): had clothing pulled in a sexual way(95\%); had clothing pulled off or down (85\%); forced to kiss someone (69\%); and had sexual messages written about you on public walls $(85 \%)$.

\subsection{Impact of Sexual Harassment on Victims' Academic Performance}

Frequencies and percentages were calculated to determine teachers' and students' perception of the impact of sexual on victims' academic performance. Results are presented in Table 2 below:

From Table 2 above, it could be inferred that majority of the teachers and students agreed that sexual harassment has impact on academic performance. Among the negative effects of sexual harassment on victims' well- being include the following: fear on students in school; lower students' self- esteem; make students have difficulty concentrating in their studies; and enable students earn unmerited grades and can lower student' grades.

\subsection{Discussion of Results}

The finding of this study revealed that majority of teachers and students perceive sexual harassment as prevalent in tertiary institutions in Edo state of Nigeria. Also, sexual harassment has strong impact on the academic performance of victims. The range of sexual harassment reported by teachers and students in tertiary institution was extensive. This finding is consistent with previous studies on school violence to the effect that teachers and students are aware of the existence of this evil vice called sexual harassment (The Scholar, 2001; Ladebo, 2001; Adamolekun, 1989).

This study also found sexual harassment has negative impacts on the academic performance of victims. Victims of sexual harassment face some of the following problems: difficulty in concentration; fear; ill at ease; low self-esteem; and lower grades. Both teachers and students viewed sexual harassment as just part of life. This finding may not be surprising for the fact that many female students these days believe that you can use what "you have" to get what you want; and as such often make themselves available for any sexual overtures from their teachers to earn higher grades. This finding reinforces those of Okwu (2006), Kopels and Dupper (1999) and Fadipe and Oluchukwu (1999) that some female students are so morally bankrupt and rely absolutely on their womanhood to pass their examinations. They seduce fellow male students, or examiners to assist them to write their examinations or award them unwarranted grades in examinations.

This study also revealed that mode of dressing is a major cause of sexual harassment. This is finding is not surprising for the fact that most students in Nigerian tertiary institutions these days are being bedevilled with obscene dressing particularly the female students. Most girls go almost naked displaying their boobs, all in the name of fashion. This finding corroborates those of Irtwange (2004), The Scholar (2001) and Okwu (2001) that teachers and students are aware of the evil that is eroding our academic environment and the seductive dressings of the female students have profound negative effects on both the students and their teachers as they can hardly concentrate on their academic work under such an environment. 
The academic consequences of sexual harassment may also be more diffused creating an environment that truly does interferes with a student's ability to learn or participate in the school setting. The students who skip classes or do not open their mouth in class for fear of drawing misogynist remarks from their teachers or classmates, the students who avoid their academic advisors' office hours for fear of having to beat off the advances from their teachers, the female students who cannot concentrate on their studies because they worry about next encounter with their lecturers who are stalking them around campus, truly receive diminished learning experiences on the campus.

\section{Conclusion}

From the findings of this study, it can be concluded that majority of the respondents hold that sexual harassment of female students in Nigeria's tertiary institutions is highly prevalent, and that the range is highly extensive. Secondly, the experience of sexual harassment negatively impacts on the academic performance of the victims. These negative effects include: lower students' self- esteem; difficulty concentrating in their studies; and students earning unmerited grades

\section{Recommendations}

Based on the findings, this study recommended among others that there should be orientation course to sensitive students on their rights and obligations within which issues of sexual harassment must feature; that tertiary institution should provide frameworks that would allow for staff and students to dialogue on the issue of sexual harassment; and higher institutions should have a written policy for disciplining any erring staff and students on matters bothering on sexual harassment.

\section{References}

Adamolekun, O. (1989). Sexual harassment on campus: A counsellor's reflection. Nigerian Journal of Counselling and Development, 4, 53-57.

Aluede, O. O. (2000). Sexual harassment of women employees in a Nigerian university: Implications for counsellors. Guidance \& Counselling, 15(2), 27-32.

American Association of University Women. (2006). Drawing the line: Sexual Harassment on Campus. Washington, DC: Author.

Anonymous (nd). Definition of sexual harassment. [Online] Available: http://fhdafiles.hda.edu/downloads/diversity/def.ofsexualharamment (May 27, 2011)

Cohen, F. (nd). Sexual harassment. [Online] Available http://ad.net/games/sex/faq.html (May 27, 2011)

Davidson, M. J. \& Fielden, S. (1999). Stress and the working woman. In Powel, G. N (Ed), Handbook of gender and work (Pp 413-426). Thousand Oaks, CA: Sage.

Fadipe, J. O. \& Oluchukwu. (1999). Educational planning and administration in Nigeria in the $21^{\text {st }}$ Century. Ondo, Nigeria: National Institute of Educational Planning and Administration, Nigeria.

Fitzgerald, L. F., Gelfand, M. J. \& Drasgow, F. (1995). Measuring sexual harassment: Theoretical and psychometric advances. Basic and Applied Social Psychology, 17, 425-445. http://dx.doi.org/10.1207/s15324834basp1704_2

Gutek, B. A. (1993). Responses to sexual harassment. In Oskamp, A \& Costanz, M. (Eds), Gender issues in contemporary society ( $p$ p 122-131). Newbury Park, CA: Sage.

Gutek, B. A \& Koss, M. P. (1993). Changed woman and changed organization: Consequences of and coping with sexual harassment. Journal of Vocational Behaviour, 42, 28-48. http://dx.doi.org/10.1006/jvbe.1993.1003

Irtwange, S. V. (2004, April 11). Learning character and university of Agriculture, Makurdi. An Unpublished Internal Memo, Student Affairs Department, University of Agriculture, Makurdi, Nigeria.

Kopels, S. \& Dupper, D.R. (1999). School-based peer sexual harassment. Child Welfare, 78(4), 434-460.

Ladebo,O.J. (2001). Sexual harassment in academia in Nigeria: How Real? African Sociological Review, 7(1), $1-7$.

Okwu, O. J. (2006). A Critique of students vices and the effect on quality of graduates of Nigeria tertiary institutions. Journal of Social Science, 12(3), 193-198.

Ontario Secondary School Teachers' Federation. (1994). Student to student sexual harassment: Final report on Phase I. Toronto, ON: Author. 
Oppong, C. (1995). A high price to pay: For education, subsistence and a place in the job market. Health Transition Review (Supplement), 5, 35-56.

Schneider, K. T., Swan, S. \& Fitzgerald, L. F. (1997). Job-related and psychological effects of sexual harassment in the work-place: Empirical evidence from two organizations. Journal of Applied Psychology, 82(3), 401-415. http://dx.doi.org/10.1037/0021-9010.82.3.401

Stein, N., Marshall, N. L. \& Tropp, L.R. (1993). Secret in public sexual harassment in our schools. Wellesley, USA: Centre for Research on Woman and Education Fund.

The Scholar. (2001). Employers assessment of graduate in the market place. A publication of Academic Staff Union of Universities, Abuja, Nigeria.

Table 1. Respondents' Scores on Teachers and Students' Perception of the Prevalence of Sexual Harassment in Schools

\begin{tabular}{|c|c|c|c|c|c|c|c|c|c|}
\hline \multirow{4}{*}{$\begin{array}{l}\text { S/ } \\
\text { No }\end{array}$} & \multirow{4}{*}{$\begin{array}{l}\text { Forms of Sexual Harassment } \\
\text { In your, do you believe that sexual harassment exists in any of the } \\
\text { following forms in your school }\end{array}$} & \multicolumn{8}{|c|}{ Response Categories } \\
\hline & & \multicolumn{4}{|c|}{ Teachers } & \multicolumn{4}{|c|}{ Students } \\
\hline & & \multicolumn{2}{|c|}{ Agree } & \multicolumn{2}{|c|}{ Disagree } & \multicolumn{2}{|c|}{ Agree } & \multicolumn{2}{|c|}{ Disagree } \\
\hline & & $\mathrm{f}$ & $\%$ & $\mathrm{~F}$ & $\%$ & $\mathrm{f}$ & $\%$ & $\mathrm{f}$ & $\%$ \\
\hline 1 & $\begin{array}{l}\text { Receiving sexual gestures, sexual comments, looks, comments or } \\
\text { jokes }\end{array}$ & 189 & 945 & 11 & 5.5 & 199 & 99.5 & 1 & 0.5 \\
\hline 2 & Touching, punched or grabbed & 190 & 95 & 10 & 5 & 194 & 97 & 6 & 3 \\
\hline 3 & Leaned over or cornered & 168 & 84 & 32 & 16 & 184 & 92 & 16 & 8 \\
\hline 4 & Receiving sexual notes or pictures & 178 & 89 & 22 & 11 & 194 & 97 & 6 & 3 \\
\hline 5 & Pressured to do something sexual & 191 & 95.5 & 9 & 4.5 & 187 & 93.5 & 13 & 6.5 \\
\hline 6 & Forced to do something sexual & 194 & 97 & 6 & 3 & 185 & 92.5 & 15 & 7.5 \\
\hline 7 & Unintentionally rushed up against & 160 & 80 & 40 & 20 & 177 & 88.5 & 23 & 11.5 \\
\hline 8 & Had your way blocked in a sexual way & 184 & 92 & 16 & 18 & 190 & 95 & 10 & 5 \\
\hline 9 & Had clothing pulled in a sexual way & 150 & 75 & 50 & 25 & 170 & 85 & 30 & 15 \\
\hline 10 & Had clothing pulled off or down & 140 & 70 & 60 & 30 & 138 & 69 & 62 & 31 \\
\hline 11 & Forced to kiss someone & 152 & 76 & 48 & 24 & 138 & 69 & 62 & 31 \\
\hline 12 & Had sexual messages written about you on public walls? & 160 & 80 & 40 & 20 & 170 & 85 & 30 & 15 \\
\hline
\end{tabular}


Table 2. Teachers and Students' Perception of Impact of Sexual Harassment on Victims' Academic Performance

\begin{tabular}{|c|c|c|c|c|c|c|c|c|c|}
\hline $\mathrm{S} / \mathrm{N}$ & Impact of Sexual Harassment & \multicolumn{8}{|c|}{ Response Categories } \\
\hline & \multirow{3}{*}{$\begin{array}{l}\text { In your school, do you believe that sexual harassment } \\
\text { impacts on academic performance in any of the following } \\
\text { ways }\end{array}$} & \multicolumn{4}{|c|}{ Teachers } & \multicolumn{4}{|c|}{ Students } \\
\hline & & \multicolumn{2}{|c|}{ Agree } & \multicolumn{2}{|c|}{ Disagree } & \multicolumn{2}{|c|}{ Agree } & \multicolumn{2}{|c|}{ Disagree } \\
\hline & & $\mathrm{f}$ & $\%$ & $\mathrm{f}$ & $\%$ & $\mathrm{f}$ & $\%$ & $\mathrm{f}$ & $\%$ \\
\hline 1 & $\begin{array}{l}\text { Sexual harassment in form of giving gratification for marks } \\
\text { does not have any effect on student's academic performance. }\end{array}$ & 35 & 17.5 & 165 & 82.5 & 20 & 10 & 180 & 90 \\
\hline 2 & $\begin{array}{l}\text { Sexual harassment in form of bribery or "blocking is no big } \\
\text { deal. }\end{array}$ & 190 & 95 & 10 & 5 & 194 & 97 & 6 & 3 \\
\hline 3 & Mode of dressing is a major cause of sexual harassment. & 185 & 92.5 & 15 & 7.5 & 174 & 87 & 26 & 13 \\
\hline 4 & Sexual harassment creates fear on students in schools & 145 & 72.5 & 55 & 27.5 & 194 & 97 & 6 & 3 \\
\hline 5 & Sexual harassment can lower student's self-esteem. & 160 & 80 & 40 & 20 & 120 & 60 & 80 & 40 \\
\hline 6 & $\begin{array}{l}\text { Sexual harassment can make students have difficulty } \\
\text { concentrating in their studies. }\end{array}$ & 194 & 97 & 6 & 3 & 185 & 92.5 & 15 & 7.5 \\
\hline 7 & $\begin{array}{l}\text { Sexual harassment can enable students earn unmerited } \\
\text { grades. }\end{array}$ & 190 & 90 & 10 & 5 & 187 & 93.5 & 13 & 6.5 \\
\hline 8 & Sexual harassment can lower student's grades. & 184 & 92 & 16 & 18 & 197 & 98.5 & 3 & 1.5 \\
\hline
\end{tabular}

